\title{
Non-uniform distribution of islet amyloid in the pancreas of 'maturity-onset' diabetic patients
}

\author{
A. Clark ${ }^{1}$, R. R.Holman ${ }^{1}$, D. R. Matthews ${ }^{1}$, T. D. R. Hockaday ${ }^{2}$ and R.C.Turner ${ }^{1}$ \\ ${ }^{1}$ Diabetes Research Laboratories, and ${ }^{2}$ Sheik Rashid Research Unit, Radcliffe Infirmary, Oxford, UK
}

Summary. Quantitative morphometry of the pancreases of five 'maturity-onset' diabetic subjects has demonstrated more amyloid in islets of the head, body and tail (where it was found in a mean $29 \%$ of the islets occupying a mean $11 \%$ islet area) than in islets of the 'pancreatic-polypeptide-rich' lobule of the head (where amyloid was found in a mean of $3 \%$ of the islets occupying a mean of $0.7 \%$ islet area, both $p<0.005$ ). The nonuniform amyloid distribution may relate to the hormone con- tent of the islet; the head and tail contained significantly more $\mathrm{A}, \mathrm{B}$ and D-cells than the pancreatic-polypeptide-rich lobule in both non-diabetic subjects $(n=8)$ and diabetic patients $(n=5 ; p<0.005)$. This result is compatible with the previous suggestion that amyloid may be derived from insulin or its precursors.

Key words: Quantitative morphometry, amyloid, diabetes.
Westermark and Wilander reported that amyloid protein in the pancreatic islets of 'maturity-onset' diabetic patients has immunological similarities to the $B$ chain of insulin [1]. Amyloid deposits are often found in the islets of non-insulin requiring diabetic patients [2] and are also associated with insulinomas [3]. We have investigated the distribution of intra-islet amyloid, in 'maturity-onset' diabetic patients, in that part of the pancreas containing high concentrations of insulin and glucagon and in the lobules of the pancreatic head which have islets with fewer B and A cells and many pancreatic-polypeptide-secreting cells ('PP-rich' lobules).

\section{Material and methods}

Post-mortem pancreatic resection was carried out within $21 \mathrm{~h}$ of death on five 'maturity-onset' diabetic patients (aged 68-84 years) and eight non-diabetic subjects (aged 58-78 years) (Table 1). Formol-saline fixed tissue blocks were taken for histology from four regions of the pancreas; (a) 'PP-rich' lobules, (b) 'PP-poor' lobules of the head, (c) body and (d) tail. Cells containing insulin (B cells), glucagon (A cells), pancreatic polypeptide (PP-cells) and somatostatin (D cells) were stained on $5 \mu \mathrm{m}$ thick serial sections using the immunoperoxidase method [4] and hormone specific antibodies. Islet amyloid stained with alkaline congo red was a pink colour in transmitted light and showed the characteristic green 'bi-refringence' in polarized light.

Morphometry was by a manual optical picture image analyser (Model MOP-03, Kontron, Meßgeräte, FRG) on an image of the histological section magnified $\times 630$. Measurements were made on 100 islets in adjacent fields of stained slides. The following variables were estimated: (1) islet area, (2) peroxidase stained areas for each hormone type and (3) area of intra-islet amyloid.

A logarithmic transform was used to achieve a normal distribution of the area data and geometric mean values are shown in Table 2. A mean of the results from the 'PP-poor' region of the head, body and the tail is presented as 'glucagon-rich' islet data. Mean islet area for the 'PP-rich' islets and the 'glucagon rich' islets was calculated from measurements made on sections stained for pancreatic polypeptide and insulin respectively.

The ratio of peptide and amyloid to the islet area was calculated for each stained section separately. The islet population counted for each stain was not quite identical. Therefore, the percentage data, although comparable, may not total $100 \%$ in a given region.

The statistical significance of results was calculated by the Mann Whitney U test.

\section{Results}

Sections from all of the diabetic patients contained large intra-islet amyloid deposits (up to 80\% of islet area) which were not seen in the control tissue. The am-

Table 1. Clinical characteristics of 'maturity-onset' diabetic and non-diabetic subjects

\begin{tabular}{|c|c|c|c|c|c|c|c|}
\hline & $\begin{array}{l}\text { Age } \\
\text { (years) }\end{array}$ & $\operatorname{Sex}$ & $\begin{array}{l}\text { Age at } \\
\text { diagnosis } \\
\text { (years) }\end{array}$ & $\begin{array}{l}\text { Time from } \\
\text { death to } \\
\text { post-mortem } \\
\text { (h) }\end{array}$ & Cause of death & Treatment & $\begin{array}{l}\text { Mean random } \\
\text { blood glucose } \\
(\mathrm{mmol} / \mathrm{l})\end{array}$ \\
\hline $\begin{array}{l}\text { Diabetic } \\
\text { patients }\end{array}$ & $\begin{array}{l}84 \\
76 \\
78 \\
68 \\
83\end{array}$ & $\begin{array}{l}\mathrm{F} \\
\mathrm{M} \\
\mathrm{F} \\
\mathrm{M} \\
\mathrm{M}\end{array}$ & $\begin{array}{l}72 \\
59 \\
74 \\
53 \\
77\end{array}$ & $\begin{array}{r}18 \\
15 \\
21 \\
3 \\
16\end{array}$ & $\begin{array}{l}\text { Pneumonia } \\
\text { Pneumonia } \\
\text { Myocardial infarction } \\
\text { Myocardial infarction } \\
\text { Pneumonia }\end{array}$ & $\begin{array}{l}\text { Glibenclamide } \\
\text { Glibenclamide, insulin } \\
\text { Glibenclamide } \\
\text { Glibenclamide } \\
\text { Glibenclamide }\end{array}$ & $\begin{array}{r}9.2 \\
14.2 \\
10.4 \\
7.0 \\
9.6\end{array}$ \\
\hline $\begin{array}{l}\text { Non-diabetic } \\
\text { subjects }\end{array}$ & $\begin{array}{l}78 \\
58 \\
70 \\
79 \\
63 \\
72 \\
67 \\
67\end{array}$ & $\begin{array}{l}F \\
M \\
F \\
F \\
M \\
F \\
M \\
F\end{array}$ & & $\begin{array}{r}6 \\
11 \\
4 \\
11 \\
5 \\
3 \\
5 \\
21\end{array}$ & $\begin{array}{l}\text { Left ventricular failure } \\
\text { 'Stab wound' } \\
\text { Haemopericardium } \\
\text { Stroke } \\
\text { Myocardial infarction } \\
\text { Myocardial infarction } \\
\text { Cardiac failure } \\
\text { Carcinoma of ovary }\end{array}$ & & \\
\hline
\end{tabular}


Table 2. Mean area per islet for five 'maturity-onset' diabetic and eight non-diabetic subjects

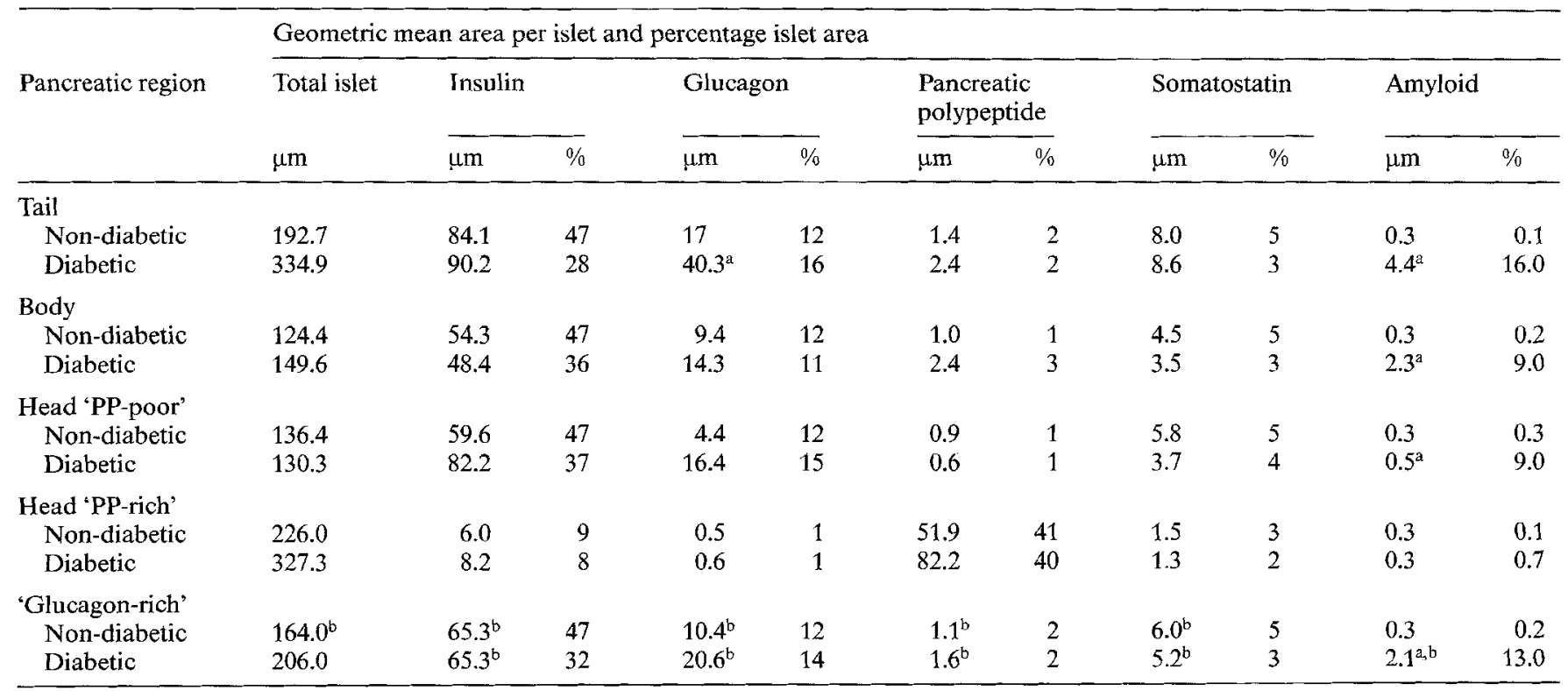

a $p<0.05$, significant difference between diabetic and controls; ${ }^{\mathrm{b}} p<0.05$, significant difference between 'glucagon-rich' and 'PP-rich' regions

yloid was usually surrounded by endocrine cells, some of which showed staining for insulin.

The amyloid occurred mainly in the 'PP-poor' region of the head, body and tail ('glucagon-rich islets'), where it was found in a mean of $29 \%$ of the islets of the diabetic patients. This contrasted with the 'PP-rich' lobules of the head where amyloid was present in a mean of $3 \%$ of the islets $(p<0.005)$. There was significantly less amyloid per islet area in the 'PP-rich' region compared with the 'glucagon-rich' islets $(p<0.001$; Table 2$)$. The 'PP-rich' islets had significantly more PP-cell area per islet than islets from other regions $(p<0.005)$ and had significantly less $\mathrm{B}, \mathrm{A}$ and $\mathrm{D}$ cell area than islets in other regions $(p<0.005)$.

\section{Discussion}

The relative absence of amyloid in the 'PP-rich' lobule of the pancreas may be related to the endocrine cell population of these islets. The 'PP-rich' lobules are thought to originate from the ventral pancreatic primordium [5] which, although morphologically similar to the remainder of the pancreas, contains islets which are histologically different. Thus, the absence of amyloid in this region could reflect the low proportion of $\mathrm{A}$, $\mathrm{B}$ and D cells or the higher number of PP-cells. A lower prevalence of amyloid in islets of the head compared with the tail was reported by Westermark and Wilander [2], but there was no separation of data from the two regions of the head.

An association between amyloid of polypeptideproducing tumours and the secreted hormone has been suggested [6] and demonstrated in a medullary carcinoma of the thyroid [7]. Amyloid is found more frequently in tumours producing insulin than those secreting glucagon [3] and the fibrils lie in close approximation to the membranes of the islet B cells [8]. The finding that islet amyloid fibrils and the $B$ chain of insulin have antigenic determinants in common [1] supports the hypothesis that the fibrils originate from insulin or its precursors. The non-uniform distribution of pancreatic amyloid and its association with islets containing many $B$ cells is compatible with this hypothesis.

Acknowledgements. We are grateful to Drs. P. R. Millard, J. K.Cruickshank and D. Lovell for the post-mortem examinations and to the Allen Fund and the British Diabetic Association for financial support.

\section{References}

1. Westermark P, Wilander E (1983) Islet amyloid in Type 2 (non-insulin-dependent) diabetes is related to insulin. Diabetologia 24: 342-346

2. Westermark P, Wilander $\mathrm{E}$ (1978) The influence of amyloid deposits on the islet volume in maturity-onset diabetes mellitus. Diabetologia 15: 417-421

3. Westermark P, Grimeluis L, Polak JM, Larsson L-I, Van Noorden S, Wilander E, Pearse AGE (1977) Amyloid in polypeptide hormone producing tumours. Lab Invest 37:212-215

4. Nakane PK, Pierce GB (1967) Enzyme labelled antibodies for the light and clectron microscopic localization of tissue antigens. J Cell Biol 33: 307-318

5. Malaisse-Lagae F, Stefan Y, Cox J, Perrelet A, Orci L (1979) Identification of a lobe in the adult human pancreas rich in pancreatic polypeptide. Diabetologia 17:361-365

6. Pearse AGE, Ewen SWB, Polak JM (1972) The genesis of apudamyloid in endocrine polypeptide tumours: histochemical distinction from immunamyloid. Virchows Arch (Abt B) 10:93-107

7. Sletten K, Westermark P, Natvig JB (1976) Characterization of amyloid fibril proteins from medullary carcinoma of the thyroid. $J$ Exp Med 143: 993-998

8. Westermark P (1973) Fine structure of islets of Langerhans in insulin amyloidosis. Virchows Arch (Abt A) 359:1-18

Received: 12 December 1983

and in revised form: 2 July 1984

Dr. A. Clark

Diabetes Research Laboratories

Radcliffe Infirmary

Woodstock Road

Oxford, OX2 6HE

UK 